\title{
After Finitude and the Question of Phenomenological Givenness
}

\author{
J. Leavitt Pearl
}

Quentin Meillassoux's 2006 After Finitude offered a sharp critique of the phenomenological project, charging that phenomenology was one of the "two principal media" of correlationism-ultimately reducible to an "extreme idealism." Meillassoux grounds this accusation in an account of givenness that presupposes that "every variety of givenness" finds its genesis within the positing of the subject. However, this critique fails to hit its mark precisely because it presupposes an account of intuitive givenness that is entirely foreign to the phenomenological project. Quite against Meillassoux's conflation of givenness, the world-for-us, and the positing subject - the very center of the phenomenological project is the recognition that intuitive givenness cannot be reduced to the constructive activity of the subject. Givenness is marked by a heterogeneity; givenness refers to what is given to us, not to what emerges from us.

Shall I say: only phenomena are truly given to the cognizing subject, he never does and never can break out of the circle of his own mental processes, so that in truth he could only say: I exist, and all that is not-I is mere phenomenon dissolving into phenomenal connections? Am I then to become a solipsist? This is a hard requirement (Husserl, The Idea of Phenomenology 16).

Since its origin, the speculative realist movement has remained hostile to the phenomenological project, particularly in its Husserlian and theological manifestations. Although some speculative realists maintain a less overtly hostile comportment to phenomenology - for example, Graham Harman's commendation of Being and Time's "tool analysis" (Sparrow 114-145)—Quentin Meillassoux's critique of phenomenology as an idealism and as one of the "two principal media" (Meillassoux, After Finitude 6) of correlationism - together with analytic philosophy-has nonetheless remained the norm.

Yet, Meillassoux grounds these accusations upon an account of givenness that presupposes that "every variety of givenness" finds its genesis within the positing of the subject - that it is only the world-for-us which gives, and it only gives to subjects capable of receiving it. This critique fails to hit its mark precisely because it presupposes an account of 
intuitive givenness that is completely foreign to the phenomenological project. Quite against Meillassoux's conflation of givenness, the world-forus, and the positing subject - the very center of the phenomenological project is the recognition that intuitive givenness cannot be reduced to the constructive activity of the subject; givenness is given to us, it does not emerge from us. Rather, givenness - paradigmatically fulfilling intuitive givenness - is given from and by the phenomenon under investigation.

\section{Phenomenology as Correlationism}

Louis Morelle suggests that amid significant divergences among various speculative realists, the critique of correlationism remains "the only agreed upon reference point" (242). Nevertheless, the precise meaning of "correlationism" has been subject to considerable debate. Michael Austin describes the concept, writing:

Correlation is the often unstated view that being only exists for subjects, that there is a direct correlation between subjective mind and the world of objects, or perhaps more accurately, that thinking beings have no access to the world except by way of cognition, so that any claim to think or discuss things-in-themselves is taken as either imaginative whimsy or pure absurdity. (48)

Meillassoux designates this admittedly broad category "the contemporary opponent of any realism" (Time Without Becoming 9), grouping together a wide variety of philosophical positions and schools: phenomenology, analytic language philosophy, post-structuralism, historicism, and German idealism, among others. Given this breadth, correlationism is often derided as a straw-man or as a troublingly ambiguous concept. John Caputo, for example, writes that the realist "victory over a straw 'correlationism' is a conquest of a non-existent country, or at most of an unoccupied one. ... The moment you supply a proper name for a world-denying, so-called correlationist ... it takes very little effort to show that the claim is ridiculous" (The Insistence of God 209). Nevertheless, for Meillassoux these diverse traditions are indeed united by a commitment to the constitution of reality by an extrinsic factor-"his [sic] viewpoint, or his categories, or his epoch, or his culture, or his language, etc." (Time Without Becoming 9). Correlationism is a philosophy of access: according to which, Meillassoux argues, "we only ever have access to the correlation between thinking and being, and never to either term considered apart from the other" (After Finitude 5).

The full consequences of Meillassoux's critique for phenomenological philosophy have been most thoroughly unpacked by Tom Sparrow's 2014 book, The End of Phenomenology. There, Sparrow takes the work of speculative realism in general, and Meillassoux in 
particular, as a starting point for a rigorous analysis and critique of the limits of phenomenology. The initial result of this critique is the assertion that phenomenology amounts to "nothing more than a modified version of idealism, Kantianism by another name" (12). Yet, this accusation of transcendental idealism is, for Meillassoux (and perhaps even more strongly for Sparrow), also paired with a deeper accusation of metaphysical antirealism: "no matter how it is interpreted," Sparrow remarks, "phenomenology can only align itself with antirealism" (18). What is this anti-realism for the Meillassouxian paradigm? "Every variety of correlationism," Meillassoux characteristically argues, is ultimately revealed "as an extreme idealism" (After Finitude 18). What this terminological shift from transcendental idealism to "anti-realism" or "extreme idealism" indicates is that, for Meillassoux and his representatives, phenomenology does not simply represent "Kantianism by another name," but more strongly, subjective or metaphysical idealism. As Sparrow suggests, "perhaps more curiously, [phenomenology is] a rigorous retooling of Berkeleyan idealism" (82).

\section{Meillassoux's Critique of Phenomenology}

Meillassoux's critique of correlationism (and thus of phenomenology) begins with some basic facts of natural-scientific discourse: the universe is 13.5 billion years old, the earth is 4.56 billion years old, life is 3.5 billion years old, and humankind is merely 2 million years old (After Finitude 9). In After Finitude, the question posed by these ancestral statements is that of the prior-to-givenness itself: what was there, before we (i.e. conscious beings) were? For Meillassoux, the failure of correlationist discourse is its inability to offer a coherent response to this question. The correlationist must assert that the subject of ancestral statements-as a given phenomenon - is not anterior to givenness. Rather, this phenomenon merely "gives itself as anterior to givenness" (14). On Meillassoux's account, this is a wholly insufficient —even paradoxical—claim. The correlationist lacks the ability to speak meaningfully of that which precedes consciousness. Or, in his own words, "contemporary philosophers have lost ... that outside which was not relative to us, and which was given as indifferent to its own givenness to be what it is, existing in itself regardless of whether we are thinking of it or not" (7).

Meillassoux suggests that the standard correlationist (and therefore phenomenological) approach to this challenge is to identify it as a "trivial" variant of the problem of the un-witnessed. For the correlationist, statements about the merely unwitnessed simply describe what one would have experienced if one had been there to witness the phenomenon. For this view, the deep ancestrality of the arche-fossil is not meaningfully distinct from any other spatially or temporally distant event. But, Meillassoux notes, the 
traditional argument from the un-witnessed "poses no danger to correlationism ... [only] because this objection bears upon an event occurring when there is already givenness" (20). For Meillassoux, this traditional response fails to contend with the full force and radicality of his argument from ancestrality. It is not simply the case that ancestral phenomena give themselves as past, that is, temporally distant. Rather, Meillassoux argues, "fossil-matter is the givenness in the present of a being that is anterior to givenness; that is to say, that an arche-fossil manifests an entity's anteriority vis-à-vis manifestation" (14). The arche-fossil is qualitatively different from the mundane un-witnessed, it "designates an event anterior to terrestrial life and hence anterior to givenness itself" (20); it is "that which is prior to givenness in its entirety" (21). Such a proposal, Meillassoux argues, cannot be encountered by the post-critical correlationist as anything other than an absurdity (14), a seemingly irredeemable paradox wherein manifestation precedes manifestation.

In After Finitude, this paradox is defused by an insistence upon a reality that exceeds and, most importantly, antedates human experience. Ancestral statements (e.g. the universe is 13.5 billion years old) and their correlates (the arche-fossil) demand that we recognize the existence of realities that precede every variety of givenness: "the ancestral does not designate an absence in the given, and for givenness, but rather an absence of givenness as such" (21). The arche-fossil is not a gap within a world of givenness, but a remnant of a time before the world of givenness existed. In the words of Rodrigo Nunes, "the arche-fossil indexes a lacuna of manifestation rather than in manifestation - not a spatio-temporally distant event or being, but specifically one that is prior to any correlation" ("ArcheFossil" 26).

In order to justify discourse about such phenomena-phenomena from "before" givenness-Meillassoux posits a temporal genesis of givenness itself. "The time at issue here," he argues, "is the time wherein consciousness as well as conscious time have themselves emerged in time. ... the ontological problem of the coming into being of givenness as such" (After Finitude 21). This genesis, Meillassoux argues in After Finitude, is nothing other than the evolutionary emergence of consciousness and its correlate: the world-for-us. With the introduction of the notion of the worldfor-us, the paradox is resolved and the critique is clarified. The error of the correlationist is not that they posit a correlation between givenness and the world-for-us - a correlation that Meillassoux will insist upon. The correlationist error consists in failing to recognize a more primordial world of "Being" that precedes this phenomenal world: the correlationist "cannot think a world without an entity capable of receiving this givenness" (37). What is necessary in order to account for the ancestral is the recognition that the world-for-us - the world that finds its genesis within time-is not the same world that exists for things-in-themselves. These two worlds - the 
world-for-us and the world of Being (or the in-itself) - must remain conceptually distinct.

This insistence upon the temporal genesis of givenness and its correlate world-for-us requires a novel account of givenness. For Meillassoux, givenness is inextricably bound to the subject to whom it is given. As he puts it, "a world is meaningful only as given-to-a-living (or thinking)-being" (After Finitude 15). The importance of this composite, "given-to-a-living (or thinking)-being" must not be underestimated. It does not merely demarcate a region of givenness; it is not, for instance, a species of the genus givenness. Rather, "given-to-a-living (or thinking)-being" is identical to givenness as such. There is an identity, Meillassoux suggest in Time Without Being, between that which "is given to you" and that which is "posited by you" (10).

This subtle identification of the subject's positing and givenness can already be traced throughout the argument from ancestrality. What Meillassoux shows is that ancestral statements describe, in the words of Nunes, "any reality prior to the emergence of the human species, or of life on earth in general" ("Ancestrality" 22). Yet, in his account of the correlationist rejoinder, Meillassoux insists that the proper correlationist response is not that the arche-fossil "gives itself as anterior to the human species or life in general" (that is, any subject whatsoever), but that it "gives itself as anterior to givenness" (After Finitude 14). In Meillassoux's analysis, givenness has become identical to the positing of the subject: givenness has become givenness to a subject, or more strongly, the subject has become the genesis of all givenness. ${ }^{1}$

\section{Phenomenology as Transcendental Idealism}

Before turning to the question of givenness, it will be helpful to clarify the present critique of Meillassoux by explicitly noting a key point of agreement. The present argument does not challenge the identification of phenomenology as a variety of transcendental idealism. While it is possible that the transcendental character of phenomenological analysis remains a viable target of critique, this question must be reserved for its own

\footnotetext{
${ }^{1}$ There is, logically speaking, a second option. Meillassoux might instead insist that the birth of consciousness miraculously triggered the emergence of givenness from heterogeneous natural-scientific objects. But, such an argument would require that at the emergence of consciousness, all beings-regardless of how spatially or temporally distant-should suddenly give themselves in a way that they had never before given themselves. Such a solution seems to prima facie raise more questions than it answers. Therefore, the present argument will presume the more direct solution that, on Meillassoux's account, givenness is identical to the positing of the subject.
} 
investigation. ${ }^{2}$ Instead, the present investigation will remain narrowly focused on Meillassoux's shift from the accusation of weak-correlationism (i.e. transcendental idealism) to the accusation of "extreme idealism" (i.e. subjective, or metaphysical idealism).

In Husserl: An Analysis of His Phenomenology, Paul Ricoeur summarily states that "the phenomenology elaborated in [Husserl's] Ideas $I$ is incontestably an idealism, even a transcendental Idealism" (24). This assertion - particularly with the final clause's emendation of transcendental idealism - is an accurate accounting of Husserl. At least as early as 1905's Philosophy as Rigorous Science, Husserl became convinced that phenomenology must take the form of a transcendental philosophy. This "transcendental turn" would culminate in Ideas I, a text whose transcendental character would scandalize many of his early followers. As he will later write in the Cartesian Meditations, "phenomenology seems to be rightly characterized as [a] transcendental theory of knowledge" (81).

Phenomenology, on this account, is a transcendental idealism because it is oriented toward the systematic explication of the structures of constitution. This identification of phenomenology (at least, intentional phenomenology) and transcendental idealism is, for Husserl, not only possible, but necessary. "Only someone who misunderstands either the deepest sense of intentional method, or that of transcendental reduction, or perhaps both," he writes, "can separate phenomenology from transcendental idealism" (Cartesian 24). Transcendental phenomenology, unlike merely eidetic phenomenology, is not content to merely explicate intentional phenomena. Instead, transcendental phenomenology turns with equal vigor toward the constitutive structures of phenomenality-intentionality, the noetic/noematic correlation, et al-that transcendentally determine that which can appear within the horizon of visibility. These transcendental conditions of constitution are identified through an egological analysis of the constituting subject. Such an approach seems, prima facie, to rightly mark Husserlian phenomenology as a species of transcendental idealism.

Much of the later Heideggerian and post-Heideggerian phenomenological tradition will reject Husserl's transcendental language in exchange for existential (e.g. Heidegger and Sartre) or embodied (e.g. Merleau-Ponty) language. Nevertheless, understood in its most general terms, this tradition maintains a broadly transcendental posture. Heidegger, for example, uses his 1929 analysis of Kant's first Critique, Kant and the Problem of Metaphysics to remark on the relationship between his own

${ }^{2}$ I would point readers to the innumerable engagements with the question of the "transcendental" character of phenomenology more broadly, and Husserl more specifically. Examples of this work include Luft, "From Being to Givenness and Back"; Heinämaa et al., Phenomenology and the Transcendental; Mohanty, Phenomenology; and Holmes, "Is Transcendental Phenomenology Committed to Idealism?" 
existential project (particularly that of Being and Time) and the critical/transcendental tradition inaugurated by the Critique of Pure Reason. There Heidegger both cites and glosses a key passage in which Kant defines the "transcendental" orientation of his idealism.

[Kant states,] "I entitle transcendental all knowledge which is occupied not so much with objects as with the mode of our knowledge of objects insofar as this mode of knowledge is to be possible a priori." Thus, transcendental knowledge does not investigate the essent [Seiende] itself but the possibility of the precursory comprehension of the Being [Sein] of the essent. (20)

Setting aside the tendential nature of Heidegger's reading of Kant, it is nevertheless the case that by his own definition, a project is transcendental insofar as it turns from beings (Seiendes) to the Being (Sein) of beings. This is, in fact, precisely how Heidegger will define his own existential project. As he argues in his 1927 lecture course, published as The Basic Problem of Phenomenology, "for us, phenomenological reduction means leading phenomenological vision back from the apprehension of a being, whatever may be the character of that apprehension, to the understanding of the being of this being (projecting upon the way it is unconcealed)" (21). Although Heidegger will prefer the realist language of the Logical Investigations to the transcendental language of Ideas $I$, he nevertheless seeks to turn from a direct engagement with phenomena (beings) toward the constitutive conditions of phenomena (their Being, their mode of unconcealment). This comportment suggests that Heideggerian existential phenomenology remains, in the broadest conception of the term, a transcendental project.

This general posture can be seen to continue throughout the proceeding post-Heideggerian phenomenological tradition. Maurice Merleau-Ponty will argue for the body as a condition for the constitution of perceptual objects in Phenomenology of Perception (1945), Michel Henry will mark the self-affection of life as the condition from the constitution of transcendent objects of consciousness in The Essence of Manifestation (1963), and Jean-Luc Marion will rigorously emphasize phenomenology's limited focus upon the possibility of phenomena, not their actuality. "Of itself," Marion characteristically writes, "phenomenology can identify the saturated phenomenon of the being-given par excellence only as a possibility. ... Its phenomenological analysis therefore bears only on its representation, its 'essence,' and not directly on its being-given" ("Metaphysics and Phenomenology" 590).

While a full treatment of the question of the relationship between phenomenology and transcendental philosophy is certainly beyond the scope of the present investigation, the preceding discussion is intended to delimit the discussion and sharpen the critique of Meillassoux. For, as I have shown above, it is not unreasonable to identify phenomenology as a species 
of transcendental idealism insofar as its investigation is directed not simply at phenomena, but upon the conditions for their constitution (Husserl), unconcealing (Heidegger), or possibility (Marion).

Yet, even given this use of the language of "transcendental idealism," Husserl and the proceeding tradition remain insistent that this transcendental turn is not reducible to a subjective (or "psychological") idealism. As Husserl writes:

Carried out with this systematic concreteness, phenomenology is eo ipso 'transcendental idealism,' though in a fundamentally and essentially new sense. It is not a psychological idealism [e.g. Berkley] ... nor is it a Kantian Idealism. ... On the contrary, we have here a transcendental idealism that is nothing more than a consequentially executed self-explication in the form of a systematic egological science, an explication of my ego as subject of every possible cognition, and indeed with respect to every sense of what exists. (Cartesian 24)

For Husserl, to declare phenomenology a subjective or psychological idealism is to misunderstand the fundamental gestures of the transcendental turn. It is, on Husserl's account, to fail to understand the nature of the phenomenological reduction and the suspension of the "general thesis"; it is to improperly permit judgments regarding the spatio-temporal reality of the world to re-enter the domain of inquiry from which they should be rightly barred. As Richard Holmes writes:

Husserl's transcendental phenomenology, which he labels transcendental idealism, is epistemologically idealistic but metaphysically neutral. ... that metaphysical neutrality is not a deficiency of his philosophy but that such is the necessary conclusion of any philosophy that successfully adheres to the policy of describing, explicating and accepting all objectivities only as they present themselves to the consciousness of them, and in terms of the consciousness of them. (98)

Nevertheless, stepping beyond this Husserlian argument, I would here like to suggest that the ability of phenomenology to remain metaphysically neutral requires more than the phenomenological reduction and the suspension of the general thesis. Rather, this neutrality requires an understanding of the heterogenous nature of phenomenological givenness. This account of givenness is radically distinct from that presupposed by Meillassoux in After Finitude. In the following sections, this account of phenomenological givenness and its relevance to Meillassoux's accusation of "extreme idealism" (subjective idealism) will be laid out through an examination of Husserl and Jean-Luc Marion's accounts of givenness respectively. 


\section{Edmund Husserl on Intuitive Givenness}

For Edmund Husserl, the foundation of phenomenology constituted a "breakthrough" (Husserl, Logical Investigations 3) precisely to the extent that it opened the way for a new mode of evidence. In order to ground the natural and logical sciences, Husserl found it necessary to develop the phenomenological method, a methodology capable of breaking the binding aporias of traditional metaphysics. By undertaking a reduction of every metaphysical positing (including, principally, the "general thesis" of the existence of the world (Husserl, Ideas I 55-60), the phenomenological method promised to grant unprecedented access to the "things themselves" (die Sachen selbst), ${ }^{3}$ an access that is uniquely verified by intuitive givenness. The priority of this intuitive verification (what Husserl calls "fulfillment") is presented in the founding principle of phenomenology, the principle of principles:

every primordial dator Intuition ["originally given intuition"] is a source of authority for knowledge, that whatever presents itself in "intuition" in primordial form (as it were in its bodily reality), is simply to be accepted as it gives itself out to be, though only within the limits in which it then presents itself. (Husserl, Ideas I 43) ${ }^{4}$

For Husserl, standard phenomena consist of two principal components. The first is intentionality: this is the active, "directed" character of all experience. As he writes in Ideas I:

It belongs as a general feature to the essence of every actual cogito to be a consciousness of something. ... All experiences which have these essential properties in common are also called 'intentional experiences' (acts in the very wide sense of the Logical Investigations); in so far as they are consciousness of something they are said to be 'intentionally related' to this something. (67)

Ideally, this intentionality finds fulfillment through a correlation with a direct intuition, the second component of the basic phenomenon. Intuition

\footnotetext{
${ }^{3}$ Husserl's notion of the "things themselves" (die Sachen selbst) should not be confused with the Kantian thing-in-itself (Ding an sich). Rather, Husserl rigorously distinguishes the Sache - understood to be the immanent, meaningful object of consciousness-from the Ding, the object of real being. Concerning the latter, he writes, "thus the Thing itself [Ding selbst], simpliciter, we call transcendent" (Ideas I 79). For Husserl's rigorous distinction between these two, see Ideas I §§39-43.

${ }^{4}$ Emphasis throughout this section will be placed upon the Husserl of Ideas I, widely regarded as the more "idealist" Husserl. This approach will emphasize that even when focus is centered upon the most generously selected portions of Husserl's texts, Meillassoux's reading remains misguided. The impossibility of phenomenology as a metaphysical or subjective idealism holds all-the-stronger if one turns to Husserl's earlier texts (e.g. Logical Investigations, early lectures on internal time consciousness) or later texts (e.g. Ideas II, Analyses Concerning Active and Passive Synthesis, etc.).
} 
functions as the receptive component of fulfilled experience. Through intuition the phenomenon is given in its self-presence; it is given "bodily" (13) and in "absolute nearness" (131).

The substance of the Husserlian breakthrough is what he refers to as the "broadening" of intuitive givenness. Whereas intuitionist accounts of perceptual experience are commonplace, Husserl recognizes intuition not only as a key moment in the constitution of perceptual experience, but as a key moment in the constitution of any objective phenomenon whatsoever. "There must at least be," Husserl insists, "an act which renders identical services to the categorial elements of meaning that merely sensuous perception renders to the material element" (Logical 348). Husserl names this intuition "essential insight" and insists that it holds an equal evidential weight with perceptual intuition: "essential insight is still intuition, just as the eidetic object is still an object" (Ideas I 12).

Although Meillassoux's argument pertains to the perceptual objects of natural-scientific study, and thus primarily to perceptual or "empirical" intuition, Husserl's broadening of intuition remains productive for the present investigation. For, in his insistence upon the necessity of intuition for all phenomena, not merely empirical phenomena, Husserl more clearly presents two key elements of his account of intuitive givenness that permit a clarification of the difference between the Husserlian and the Meillassouxian accounts of givenness. First, intuition is given in "grades of givenness," or levels of clarity, of which the "zero-limit is obscurity, [and] the unity-limit is full clearness" (Husserl, Ideas I 131). Second, it is only insofar as an intentionality is fulfilled that an object is constituted. "In the case of full unclearness," that is, the complete lack of intuitive givenness, Husserl writes, "the phase of givenness is not reached at all. Consciousness ... intuits no longer, in the strict sense it no longer 'gives objects' at all" (131). Together these two elements establish Husserl's understanding of intuitive givenness as holding an evidential priority that is only granted because the genesis of intuitive givenness remains heterogenous to intentionality and the constituting subject. Let us see precisely how this is the case.

According to the first element, givenness is given in grades of clearness, which is to say, there is no in-principle necessity of total fulfillment. For Husserl, there is no essential adequatio between intentionality and intuition. To the contrary, Husserl insists that certain phenomena even demand partial fulfillment: "it belongs to the type of development peculiar to certain categories of essential being that essences belonging to them can be given only 'one-sidedly,' whilst in succession more 'sides,' though never 'all sides"' (Ideas I 12). In fact, as Derrida famously exploited in "Signature Event Context," there is ultimately no 
requirement that intentionality find fulfillment at all. ${ }^{5}$ Intentionality, as an eidetic necessity, can always remain empty or unfulfilled. As John Caputo notes:

If Husserl has shown that the power of the signifier is precisely its capacity to function in the absence of intuitive fulfillment, then [Derrida argues] why measure signifiers in terms of presence rather than absence? Why not say that signifiers function all the more perfectly in their unique and distinctive role as signifiers when they are not fulfilled, and even more perfectly still when they are, in principle not fulfillable?" ("Derrida and Marion” 122)

Whereas Derrida privileges the unconstrained, unfulfilled signifier, such an emphasis is completely foreign to Husserl's epistemological proclivities. Rather, Husserl privileges the fulfillment of intentionality because, on his account, it is only the fulfilled intentionality that can function as evidence, that is, as a source for knowledge. Intuitive fulfillment is granted this unique evidential role because no objectivity manifests within an unfulfilled or empty intentionality. It is here that Husserl's first element (intuitive givenness is given in grades) comes together with his second element (only intuitive givenness "gives objects"). As he will remark in Analyses Concerning Passive and Active Synthesis, "nothing takes place genuinely in the empty presentation, an objective sense is not genuinely constituted" (114).

Nevertheless, it is necessary to ask why intuition, rather than intentionality alone, is granted this right to "give objects," and therefore, to function as evidence. The contrast between Derrida's enthusiasm for the unconstrained signifier and Husserl's insistence upon intuition as the source of right is instructive at this point. For Husserl, the unfulfilled intentionality (the Derridean unconstrained signifier) cannot function as a "source of authority for knowledge" because the lack of fulfillment makes it impossible to differentiate the veritable phenomenon from the mere imaginative fantasy of the positing subject. Just as perceptual intentionality finds its fulfillment in empirical intuition that "brings it to givenness: as perception ... in its 'bodily' selfhood. On quite similar lines, essential intuition is the consciousness of something, of an 'object,' a something toward which its glance is directed, a something 'self-given' within it" (Ideas I 13). This notion of self-givenness is central. Intuitive givenness permits a distinction between the veridical object and mere fantasy because intuition is self-given from the object of investigation. Givenness is not

${ }^{5}$ Derrida writes: "This is the possibility on which I wish to insist: the possibility of extraction and of citational grafting which belongs to the structure of every mark, spoken or written, and which constitutes every mark as writing even before or outside every horizon of semiolinguistic communication; as writing, that is, as a possibility of functioning cut off, at a certain point, from its 'original' meaning and from its belonging to a saturable and constraining context” (320). 
given by consciousness, but is rather self-given from its own ground; the given gives itself.

In the Logical Investigations, Husserl discovered that intuition and intentionality are autonomous and that there is no direct correlation between intentionality and intuition. It is now possible to spell out precisely why this is a necessity. For Husserl, these two principal components of the standard phenomenon must be recognized in their distinction because they do not share a singular genesis. Whereas intentionality is given from consciousness to itself in an act of auto-donation or self-givenness, fulfilling-intuitions proceeds from their own ground: the phenomenon itself. ${ }^{6}$ Intuitive givenness, in sum, is not an immanent component of intentionality. It strikes intentionality, and therefore the immanent region of consciousness, from the "outside." The heterogenous character of this origin must be maintained even if, falling under the bracket of the reduction, the metaphysical status of this "outside" must remain in principle ambiguous or indeterminate.

Within the Husserlian account of fulfillment, intuition's evidentiary character emerges precisely from this heterogeneity. Only the fulfilled intentionality functions as a source of right because, unlike the mere fantasy, the intuitively fulfilled phenomenon is not simply constructed by consciousness. As Jean-Luc Marion writes:

in contrast to the Cartesian or Kantian method, the phenomenological method, even when it constitutes phenomena, is limited to letting them manifest themselves. Constituting does not equal constructing or synthesizing, but rather giving-a-meaning, or more exactly, recognizing the meaning that the phenomenon itself gives from itself to itself. (Being Given 9)

This account of the heterogeneity of intuitive givenness stands directly opposed to Meillassoux's account of givenness and calls into question his accusation that phenomenology is ultimately reducible to a subjective or metaphysical idealism. As we have seen, the center of Meillassoux's critique is his presumption of an account of givenness that

\footnotetext{
6 These "fulfilling-confirming" intuitions are distinguished by Husserl from "clarifying" intuitions - "as for example when we picture an expectation that is initially empty, when we picture how it will arrive" (Husserl, Analyses Concerning Active and Passive Synthesis 122). While these clarifying intuitions do not emerge from the immediate presence of the phenomenon under investigation, they do emerge from a broader context of lived experiences (e.g. expectations based upon memories). Thus, Husserl writes, "this process of bringing to intuition is actually disclosive only with respect to those components that were, so to speak, foreseen within what was prefigured" (122). In this regard, such intuitions can be ultimately traced back to an intuitive givenness outside of the subject. Therefore, while a full treatment of clarifying intuitions is beyond the scope of the present project, it can be noted that they do not disrupt the general thesis of the present article: that intuitions are hetero-affective, that they do not originate within the subject.
} 
conflates givenness with the positing of the subject. Because givenness emerges from the subject, the phenomenologist is unable to account for the arche-fossil, the phenomenon that is antecedent to the emergence of consciousness. Unable to account for such phenomena, phenomenology is forced to deny that they can be meaningfully spoken about (phenomenology cannot make ancestral statements) and its discourse must instead resolve into a subjective idealism.

Husserl's account of phenomenological givenness, on the other hand, depends upon the self-givenness of intuition. Therefore, it is no longer self-evident that phenomenology is incapable of making meaningful ancestral statements. Rather, as an objectively constituted phenomenon, the arche-fossil is a phenomenon that remains, at least in principle, intuitively fulfillable. Capable of accounting for such ancestral statements, phenomenology does not fall victim to the accusation of subjective idealism levelled by Meillassoux in After Finitude.

\section{Marion and Radical Receptivity}

For Meillassoux and his followers, the subjective idealist bent of Husserlian phenomenology is redoubled in the post-Heideggerian phenomenology epitomized by the thinkers of the later French, so-called "theological turn" tradition. ${ }^{7}$ These thinkers, Meillassoux argues, manifest the inevitable consequence of all correlationism: fideism. Like correlationism, fideism is an intentionally broad term, intended to draw together both religious fundamentalism and the religious turn in 20th century philosophical thought. Focusing more specifically on phenomenology, Sparrow explicitly targets this French tradition, suggesting that "theological phenomenology, like fideism, makes religion out of reason by undermining the legitimacy of metaphysics and, disturbingly, opening philosophy up to mysticism and fanaticism" (82).

For Meillassoux, the emergence of fideism is directly tied to the abandonment of realist metaphysics. "The end of [realist] ideologies," he writes, "has taken the form of the unqualified victory of religiosity" (After Finitude 45). Abandoning realism, correlationist philosophy has lost an objective relation to the real. As Alain Badiou argues in the preface to After Finitude, only a return to realism would allow "thought to be destined towards the absolute once more, rather than towards those partial fragments and relations in which we complacently luxuriate while the "return of the religious' provides us with a fictitious supplement of spirituality" (viii). This return to the real would require the ability to speak about the objective world - the "great outdoors"-without recourse to the correlation. In this

\footnotetext{
${ }^{7}$ For Meillassoux's full critique of the "theological turn," see After Finitude 28-49. This is repeated and expanded by Sparrow $(52-62,82)$.
} 
regard, Meillassoux's critique of fideism is subordinated to his principal concern with anti-realism. Said otherwise, it is only insofar as Meillassoux's charge of extreme idealism holds, that contemporary phenomenology can be understood as a naive fideism. Thus, even granting the religious and theological tone of French phenomenological thought, the question still finally resolves to the nature of phenomenological givenness.

Paradigmatic of this theologically-inflected phenomenological tradition is the work of Jean-Luc Marion. While Meillassoux does not explicitly name Marion as an interlocutor, he is almost certainly the unspecified target of Meillassoux's derisive critique of those "fideists who believe that 'being is pure gift"' (72). ${ }^{8}$ Yet, quite against these accusations of fideism and subjective idealism, the radical phenomenology of Marion pursues the anti-subjective idealist character of Husserlian phenomenology to its most extreme end. This end, as in the case of Husserl, is achieved by emphasizing phenomenological givenness - an emphasis so exaggerated that Gschwandtner will write that "Marion's philosophy can be defined as a "phenomenology of Givenness"" (1).

As we have seen above, the crux of Meillassoux's argument against correlationism and phenomenology is a conception of experience that locates the genesis of givenness in the positing activity of the subject. Marion, perhaps even more than Husserl before him, remains immune to such a critique for two principal reasons. First, Marion seizes upon and expands Husserl's account of givenness and further emphasizes the alterity and heterogeneity of phenomenological givenness. Second, Marion rejects the constructive language of the ego cogito and substitutes in its place the notion of a radically passive "gifted" (l'adonné). This receptive-self lacks the active constructive power necessitated by a subjective or metaphysical idealist philosophy. By examining these two characteristics in turn, it will become apparent that Marion offers a distinctively anti-constructivist, and thereby anti-subjective idealist phenomenology.

1.) For Marion, phenomenological givenness stands as the definitive discovery of phenomenology. This emphasis is manifest in a radical reading of Husserl's "Principle of Principles" (see section IV above). Counter to its initial impression, in Marion's reading of this principle, evidential priority is not ultimately granted to intuition. Rather, Marion identifies the recurrence of the language of givenness (donation/Gegebenheit) throughout Husserl's rendering of the principle. It is not simply that intuition should be privileged, but every "originally given intuition" (originär gebende

\footnotetext{
${ }^{8}$ Marion, for his part, returns the favor, writing that "we can see here the premises of what today's so-called 'new realism' claims to be its radical innovation, which it is quite undoubtedly a regression and in any case an illusion. For nothing, no state of affairs could ever concern us (or assure us), if it did not first attain to us and affect us; otherwise put, if it never appeared to us" ("The Reduction" 44).
} 
Anschauung); intuition should be accepted only in regards to the way in which it "gives itself out to be" (als was es sich gibt). "The phenomenological breakthrough," Marion writes, "consists neither in the broadening of intuition, nor in the autonomy of signification, but solely in the unconditional primacy of the givenness of the phenomenon" (Reduction and Givenness 32).

Having chosen givenness as the central focus of his investigation, Marion is left with the task of articulating the nature or status of phenomenological givenness. This project is centered on the phenomenological principle, articulated at the culmination of Reduction and Givenness: "as much reduction, as much givenness" (203). What this principle suggests is that, for phenomenology, the question of givenness always begins with a question of access. In order to discover the givenness of the phenomenon, the phenomenologist must employ a methodology whereby givenness can be brought into focus. The proper method for this task, as the principle suggests, is the phenomenological reduction. For Marion, the ultimate aim of the reduction is the bringing into evidence of the given - "the thing itself" (Sache, not Ding) - in its purity. This is the decisive character of phenomenological philosophy: "without the reduction, no procedure of knowledge deserves the title of "phenomenology" (78).

Yet, Marion is content neither with the Husserlian transcendentalphenomenological reduction nor with the Heideggerian existential reduction. In neither of these articulations of the reduction, Marion argues, can the givenness of the phenomenon be directly accessed. Whereas the aim of the reduction is the removal of every mediator between the phenomenological investigator and the phenomenon, both the Husserlian and Heideggerian reductions maintain mediating conditions of phenomenality - horizons of visibility that delimit the precise ways in which the phenomenon might manifest. These delimiting horizons do not truly permit the manifestation of the pure givenness of the phenomenon as it gives itself to be.

For Husserl, the "reduced phenomenon" produced by the phenomenological reduction only exhibits its givenness through the horizon of consciousness or transcendental subjectivity; which, as Heidegger notes, "is already presupposed [by Husserl] as the matter of philosophy" ("The End of Philosophy" 63). That is to say, the reduced phenomenon is "the phenomenon whose mode of Being is reduced by the reduction to what the primacy of consciousness imposes upon it" (Marion, Reduction and Givenness 54). ${ }^{9}$ This presupposition of consciousness as the horizon of

\footnotetext{
${ }^{9}$ In the words of Heidegger: "the transcendental reduction to absolute subjectivity gives and secures the possibility of grounding the objectivity of all objects (the Being of this being) in its valid structure and consistency, that is, in its constitution, in and through subjectivity" ("The End of Philosophy" 63).
} 
visibility limits that which can manifest itself to that which obeys the requirements of objectivity: "every phenomenon that is not reduced to that [objective] presence is of itself excluded from phenomenality" (56). The reduced phenomenon is the object of consciousness. This limitation of givenness to consciousness can be identified in a typical introduction to a phenomenological analysis in $\S 15$ of Ideas II:

If we should touch on the thing [Sache] itself, then it is required of us, assuming we wanted to grasp the essence of the thing and determine it conceptually, that we not be content with vague locutions and traditional philosophical preconceptions but instead draw from the very source of clear givenness. Thus we have to go back, as exemplary, to the consciousness in which things are given to us originally and so perfectly that we can be lacking nothing for grasping the universal essential form which prescribes the apriori rule for such objects. (37)

For Marion, this reduction and its correlate, the reduced phenomenon, fails to live into the radicality of the phenomenological impulse. Givenness has not been accessed in its purity, the "thing itself" has not been truly reached, because the horizon of the phenomenological reduction (the phenomenological attitude) still excludes those phenomena whose mode of givenness does not lend itself to objectification: "it thus excludes from givenness everything that does not let itself be led back to objectivity, namely the principal differences of ways of Being (of consciousness, of equipmentality, of the world)" (Marion, Reduction and Givenness 204).

For Heidegger, the Husserlian reduction's inability to approach the "originary givenness" of the phenomenon requires a radical reconceptualization of the phenomenological reduction. This reorientation finds its clearest formulation in 1927 Basic Problems of Phenomenology (cited in part above), where Heidegger explicitly marks out the divergence between his own reduction and the reduction as understood by Husserl:

For Husserl, phenomenological reduction, which he worked out for the first time expressly in the Ideas Toward a Pure Phenomenology and Phenomenological Philosophy (1913), is the method of leading phenomenological vision from the natural attitude of the human being whose life is involved in the world of things and persons back to the transcendental life of consciousness and its noetic-noematic experiences, in which objects are constituted as correlates of consciousness. For us, phenomenological reduction means leading phenomenological vision back from the apprehending of a being, whatever may be the character of that apprehension, to the understanding of the being of the being (projecting upon the way it is unconcealed). (21) 
As we saw above, for Heidegger, the role of the reduction was to grant access to the Being (Sein) of beings (Seiendes) and ultimately to grant access to Being (Sein) itself as a phenomenon. In this way, Heidegger seeks to radicalize the opening granted by the sixth Logical Investigation's introduction of the categorial intuition of "Being" (see Husserl, Logical Investigations 346-348). Phenomenology, for Heidegger, is the proper route to a fundamental ontology, that is, an attempt to grasp the meaning of Being itself (Heidegger, Being and Time 34).

Yet, this fundamental ontology will only be possible if approached from the perspective of Dasein - that peculiar entity who "in its very Being, that Being is an issue for it" (32), that being to whom the Being of beings primordially discloses itself. Dasein, unlike transcendental consciousness, does not constitute, but rather is that being who always already stands "in the truth of Being" (Heidegger, "Letter on Humanism" 218). Heidegger's comments in "The Origin of the Work of Art" are exemplary of this development:

In the midst of beings as a whole an open place occurs. There is a clearing. Thought of in reference to beings, this clearing is more in being than are beings. This open center is therefore not surrounded by beings; rather, the clearing center itself encircles all that is. ... Beings can be as beings only if they stand within and stand out within what is cleared in this clearing. Only this clearing grants and guarantees to us humans a passage to those beings that we ourselves are not, and access to the being that we ourselves are. (178)

For Heidegger, this receptive approach is more capable of manifesting phenomena in their originary givenness because phenomena are not grasped or delimited by transcendental subjectivity: the truth of beings (phenomena) "is not a feature of correct propositions that are asserted of an 'object' by a human 'subject"” ("On the Essence of Truth" 127).

For Marion, this Heideggerian development of the reduction and the phenomenological-self marks a decisive step forward in phenomenology's aim to open itself to the manifestation of the phenomenon as it gives itself to be. But the receptivity of Dasein and the Heideggerian clearing nevertheless fails to complete the return to pure givenness (Marion, Being Given 34-39). Like the Husserlian reduction, the Heideggerian reduction fails to manifest the givenness of the phenomenon without condition. While it recognizes the diversity of modes of Being among beings as well as the ontological difference between Being and beings, it nevertheless limits itself to that which "is." The redoubled reduction "excludes therefore that which does not have to be, in particular the preliminary conditions of the 'phenomenon of Being' (boredom, claim, etc.)" (Reduction and Givenness 204). It is the aim of Marion to develop a still more radical conception of 
the reduction, a "third reduction" which might finally grant access to the givenness of the phenomenon without restriction.

Marion sketches out the basic moves of the third reduction in the concluding section of Reduction and Givenness. Under this third reduction, the phenomenon is reduced from every horizon of visibility, every condition, every determination. Through this radical reduction, Marion attempts to grant access to the pure givenness of the phenomenon before it is constituted as an object (Husserl) or a being (Heidegger). Such a phenomenon is not bound by the strictures of the constituting subject: that which sculpts, grasps, or controls the phenomenon. Instead, givenness is permitted to manifest as it gives itself to be: "phenomenality is not grasped: it is received" (Marion, Being Given 264).

What Marion discovers through this third reduction is that the basic structure of givenness, insofar as it can be called a structure, is that of the gift or the call. ${ }^{10}$ The third reduction, he writes, is the reduction of "every claim to the pure form of the call" (Reduction and Givenness 196). Within the purity of the call, the phenomenon manifests itself, from itself, in its radical heterogeneity. "Givenness," he writes, "goes farther than objectness and Being because it comes from farther away" (Being Given 39). The subject - or rather, "the successor to the "subject"" (268) - is here merely the respondent to the pure givenness of the call, a givenness that it has not constructed. Marion names this respondent "the gifted" (l'adonné).

2.) While much of Marion's early career was devoted to a recovery of Cartesian thought for the contemporary world, ${ }^{11}$ he nevertheless suggests that the ego cogito and its philosophical heirs remain trapped in the logic of subjectivity that would foreclose any access to the phenomenon as it gives itself. Against the Cartesian cogito and its philosophical descendantswhich Marion will trace through Heideggerian Dasein (Being Given 261) Marion develops "the gifted," that which "receives itself entirely from what it receives" (268). In a reversal of traditional constructivist accounts, Marion insists that the gifted is born in its response to a counterintentionality: that which "sees me first, because it takes the initiative" (In Excess 116). In this ultimate act of receptivity, "the call gives me to myself ... the I is only insofar as the call has always already claimed and therefore given to itself something like a myself/me" (Being Given 270). To use Marion's grammatical language, the self discovered by phenomenology is a self in the dative.

Against the impulse to control or grasp, the gifted manifests as a "filter or prism" (264), a mere screen upon which givenness projects itself.

\footnotetext{
${ }^{10}$ Here drawing upon the phenomenological work of Jean-Louis Chrétien. See, for example, Chrétien, The Call and the Response.

${ }^{11}$ See Marion, Cartesian Questions; Descartes' Grey Ontology; and Descartes' White Theology.
} 
"The receiver therefore does not only receive what gives itself," Marion suggests, "it allows the given to show itself insofar as it gives itself" (264). This passivity or receptivity grants activity, construction, and constitution merely penultimate roles in the self. This prioritization of receptivity radically differentiates the gifted from the subject of any subjective or metaphysical idealism. Quite against a subject that would function as the genesis of givenness, or who would posit the givenness of phenomena (Meillassoux's account), Marion's gifted receives itself from the givenness which it receives. The gifted is preceded by a heterogenous givenness that it does not ground; it is always already a respondent, is always anticipated by an Other that precedes it and calls it into itself (273).

\section{The Circularity of After Finitude}

What is discovered in these analyses of Husserl and Marion's accounts of phenomenology is that the phenomenological breakthrough was not the discovery of a correlation, in Meillassoux's language, of thinking and Being. Instead, a distinct correlation appears at the foundation of phenomenological thought: the correlation between that which appears and its very appearing, that is, its mode of givenness. This givenness, particularly in the paradigmatic form of fulfilling intuitive givenness, is neither constructed nor posited by the subject. Rather, as we saw in Husserl, it is only the independence of intuitive givenness from the subject (the autonomy of intentionality and intuition) that grants it the capacity to ground objectivity and to function as phenomenological and epistemological evidence. Moreover, as Marion makes all the clearer, this appeal to givenness is not a peripheral concern for contemporary phenomenology: givenness stands at the base of all appearing because, phenomenologically speaking, every appearing is the self-manifestation of the phenomenon as it gives itself to be. The ultimate consequence of this deeper correlation (the phenomenon and its givenness) is the recognition of "appearing itself no longer as a 'given of consciousness,' but indeed as the givenness to consciousness (or even through consciousness) of the thing itself" (Marion, Reduction and Givenness 33). Yet, is the recognition that phenomenology is founded upon an account of givenness that highlights its heterogeneous character sufficient to strip the teeth from Meillassoux's critique of phenomenology? An answer to this question will require the identification of a vicious circularity at the center of Meillassoux's critique of phenomenology in After Finitude.

As we have seen, Meillassoux's critique of correlationism and phenomenology is centered upon the distinction between the world-for-us and the world of Being (the world of things in-themselves). The correlationist, who restricts all knowledge to that which is given, can only speak of the world for-us and is unable to account for the veracity of 
statements regarding the world of Being (such as ancestral statements). Yet, as we have also seen, in After Finitude, Meillassoux employs an idiosyncratic account of givenness - one which is markedly distinct from the phenomenological account in its description of this world for-us. For Meillassoux, givenness is posited by the subject, it is always implicitly a "given-to-a-living (or thinking)-being." If this account of givenness is distinct from the accounts of givenness found in phenomenology, why does Meillassoux develop an account that centers givenness in this way? Simply, this account of givenness does not emerge from the disciplines under investigation - in this instance phenomenology. Rather, in a circular gesture, After Finitude draws its account of givenness from its own conclusion: subjective idealism.

By presupposing that phenomenological givenness is a product of the subject, Meillassoux has preemptively stripped heterogeneity out of its central role in phenomenology. Having stripped away this heterogeneity, all that remains for phenomenology is the world of the subject or the self. But, if one removes all heterogeneity in this manner, then one has already implicitly presupposed a subjective idealist conception of reality. To take a paradigmatic example of this approach, in the traditional reading of Fichte's 1794 Wissenschaftslehre, the text opens with the elimination of all authentic heterogeneity: "nothing is posited to begin with, except the self; and this alone is asserted absolutely" (The Science of Knowledge 104). Anything which is not this initial self, any not-I, must be posited by this initial self. " $\sim \mathrm{A}$ is posited absolutely, as such," Fichte writes, "just because it is posited" (103). Heterogeneity is an arbitrary positing of the I. It is this account of givenness - wherein givenness is the arbitrary positing of the subject - that stands at the foundation of Meillassoux's account of correlationism. To ostensibly draw the subsequent conclusion that phenomenology resolves into a subjective idealism is therefore disingenuous. Indeed, it is to state a mere tautology, even a vicious circularity. It is undoubtedly the case that phenomenology resolves into subjective idealism if one substitutes an authentically phenomenological account of givenness with an account derived from subjective idealism. But this substitution undermines Meillassoux's aspiration to discover a fatal flaw in phenomenology. He has not discovered that phenomenology was always already an "extreme idealism," he has merely turned "phenomenology" into an extreme idealism by substituting idealist presuppositions for phenomenological presuppositions.

This circularity is not merely accidental. Meillassoux explicitly admits that he constructed his account of correlationism on the model of idealism. A 2010 interview with Graham Harman is particularly instructive on this point. There, Meillassoux describes his creation of "correlationism" as a term of art: "with the invention of this term [correlationism], I wished to 'identify' a ubiquitous adversary in contemporary philosophy ... I had to 
avoid the term 'idealism,' since it is loaded with ambiguity, and since there are numerous correlationists who refuse to be recognized as idealists" (Harman 163-164). Simply put, Meillassoux never discovered a covert subjective idealism within correlationism. Rather, beginning with an account of idealism, he retrojected key components of the idealist model (particularly its conception of givenness) onto "correlationism" more broadly, and phenomenology more specifically.

The supposed paradox of the ancestral or the arche-fossil, while a perfectly coherent critique of subjective idealism, ultimately fails to address the intuitionism of phenomenology. Insofar as phenomenology does not presume the subject as the ultimate genesis of givenness, neither the archefossil nor ancestral statements constitute a challenge to phenomenological philosophy. While the phenomenologist might affirm that the ancestral statement "designates an event anterior to terrestrial life," she need not also affirm that it designates an event "anterior to givenness itself" (After Finitude 20). Because it is the phenomenon itself and not the subject or the phenomenologist that functions as the ground of givenness, the arche-fossil can give itself as anterior to the evolutionary emergence of consciousness without paradox or confusion. This givenness does not block access to the arche-fossil in-itself, but rather is the means by which one gains access to the arche-fossil. As Caputo has repeatedly affirmed, the contention of the so-called "correlationists" was never that one only has access to the correlation between thinking and being, but rather, more simply, that one only ever has access to being by thinking (or experiencing). As he writes in The Insistence of God:

Words like "interpretation" and "access" produce allergic results in the warrior realists. But the opposite of accessible objects is inaccessible objects, objects about which we know nothing. ... The question is not how to make unconditioned contact with reality but how to find the right conditions under which it is possible to make contact with reality at all. (207)

To suggest otherwise is to fundamentally misunderstand the nature of phenomenological givenness. In the words of Husserl, "if anyone objects, with reference to these discussions of ours, that they transform the whole world into subjective illusion and throw themselves into the arms of an 'idealism such as Berkeley's,' we can only make answer that he [sic] has not grasped the meaning of these discussions" (Ideas I 108). The reduction of phenomenology to subjective or metaphysical idealism is a "hard requirement," one that phenomenology cannot abide. 


\section{Works Cited}

AUSTIN, Michael. "Correlationism: Weak and Strong." The Meillassoux Dictionary. Ed. Peter Gratton and Paul J. Ennis. Edinburgh: Edinburgh University press, 2015.

CAPUTO, John D. "Derrida and Marion: Two Husserlian Revolutions." Religious Experience and the End of Metaphysics. Ed. Jeffrey Bloechl. Bloomington: Indiana University Press, 2002.

-. The Insistence of God: A Theology of Perhaps. Indianapolis: Indiana University Press, 2013.

CHRÉTIEN, Jean-Louis. The Call and the Response. Trans. Anne A. Davenport. New York: Fordham University Press, 2004.

FICHTE, Johann Gottlieb. The Science of Knowledge. Trans. And Ed. Peter Heath and John Lachs. New York: Cambridge University Press, 1982.

DERRIDA, Jacques. "Signature Event Context." Margins of Philosophy. Trans. Alan Bass. Chicago: The university of Chicago Press, 1982.

GSCHWANDTNER, Christina M. Degrees of Givenness: On Saturation in Jean-Luc Marion. Bloomington: University of Indiana Press, 2014.

HARMAN, Graham. Quentin Meillassoux: Philosophy in the Making. Edinburgh: Edinburgh University Press, 2011.

HEIDEGGER, Martin. Being and Time. Trans. John Macquarrie and Edward Robinson. New York: Harper \& Row Publishers, 1962.

-. Kant and the Problem of Metaphysics. Trans. James S. Churchill. Indianapolis: Indiana University Press, 1972.

- "Letter on Humanism." Basic Writings. Trans. Albert Hofstadter, ed. David Farrell Krell. New York: HarperCollins Publishers, 1993.

—. "On the Essence of Truth." Basic Writings. Trans. John Sallis. Ed. David Farrell Krell. New York: HarperCollins Publishers, 1993.

-. The Basic Problems of Phenomenology. Trans. Albert Hofstadter. Bloomington: Indiana University Press, 1988.

- . "The End of Philosophy." On Time and Being. Trans. Joan Stambaugh. New York: Harper \& Row, 1972.

- "The Origin of the Work of Art." Basic Writings. Trans. Albert Hofstadter. Ed. David Farrell Krell. New York: HarperCollins Publishers, 1993.

HEINÄMAA, Sara, HARTIMO, Mirja, and MIETTINEN Timo, eds. Phenomenology and the Transcendental. New York: Routledge/Taylor \& Francis Group, 2014. 
HOLMES, Richard H. "Is Transcendental Phenomenology Committed to Idealism?" The Monist 59, no. 1 (1975): 98-114.

HUSSERL, Edmund. Analyses Concerning Passive and Active Synthesis: Lectures on Transcendental Logic. Trans. Anthony J. Steinbock. New York: Springer Publishing, 2001.

-. Cartesian Meditations: An Introduction to Phenomenology. Trans. Dorion Cairns. The Hague: Martinus Nijhoff, 1973.

-. Ideas: General Introduction to Phenomenology. Trans. W. R. Boyce Gibson. New York: Routledge, 2012.

-. Ideas Pertaining to a Pure Phenomenology and to a Phenomenological Philosophy: Second Book, Studies in the Phenomenology of Constitution. Trans. Richard Rojcewicz and André Schuwer. Boston: Kluwer Academic Publishers, 1989.

-. The Idea of Phenomenology. Trans. William P. Alston and George Nakhnikian. The Hague: Martinus Nijhoff, 1964.

-. The Shorter Logical Investigations. Trans. J.N. Findlay. New York: Routledge, 2001.

LUFT, Sebastian. "From Being to Givenness and Back: Some Remarks on the Meaning of Transcendental Idealism in Kant and Husserl." International Journal of Philosophical Studies 15, no. 3 (2007): 367-394

MARION, Jean-Luc. Being Given: Toward a Phenomenology of Givenness. Trans. Jeffrey L. Kosky. Stanford: Stanford University Press, 2002.

-. Cartesian Questions: Method and Metaphysics. Chicago: University of Chicago Press, 1999.

-. Descartes' Grey Ontology: Cartesian Science and Aristotelian Thought in the Regulae. South Bend: St. Augustine's Press, Forthcoming.

-. Descartes' White Theology. South Bend: Saint Augustine's Press, Forthcoming.

-. In Excess: Studies in Saturated Phenomena. Trans. Robyn Horner and Vincent Berraud. New York: Fordham University Press, 2002.

- "Metaphysics and Phenomenology: A Relief for Theology." Trans. Thomas A. Carlson. Critical Inquiry 20, no. 4 (1994): 572-591.

-. Reduction and Givenness: Investigations of Husserl, Heidegger, and Phenomenology. Trans. Thomas A. Carlson. Evanston: Northwestern University Press, 1998.

-. "The Reduction and 'The Fourth Principle'." Trans. Daniel Gillis, Analecta Hermeneutica 8 (2016): 41-63. 
MEILLASSOUX, Quentin. After Finitude: An Essay on the Necessity of Contingency. Trans. Ray Brassier. New York: Bloomsbury, 2008.

-. Time Without Becoming. Ed. Anna Longo. Philadelphia: Mimesis International/Casemate Publishing, 2014.

MOHANTY J. N. Phenomenology: Between Essentialism and Transcendental Philosophy. Evanston: Northwestern University Press, 1997.

MORELLE, Louis. "Speculative Realism: After Finitude, and Beyond?" Speculations 3 (2012): 241-272.

NUNES, Rodrigo. "Ancestrality." The Meillassoux Dictionary. Ed. Peter Gratton and Paul J. Ennis. Edinburgh: Edinburgh University press, 2015.

—. "Arche-Fossil." The Meillassoux Dictionary. Ed. Peter Gratton and Paul J. Ennis. Edinburgh: Edinburgh University press, 2015.

RICEUR , Paul. Husserl: An Analysis of His Phenomenology. Trans. Edward G. Ballard and Lester E. Embree. Evanston: Northwestern University Press, 1967.

SPARROW, Tom. The End of Phenomenology: Metaphysics and the New Realism. Edinburgh: Edinburgh University Press, 2014. 